\title{
Potential for improving the carbon footprint of butter and blend products
}

\author{
A. Flysjö ${ }^{*} \dagger^{1}$ \\ ${ }^{*}$ Arla Foods, 8260 Viby, Denmark \\ †Aarhus University, 8830 Tjele, Denmark
}

\section{ABSTRACT}

To reduce the environmental impact of a product efficiently, it is crucial to consider the entire value chain of the product; that is, to apply life cycle thinking, to avoid suboptimization and identify the areas where the largest potential improvements can be made. This study analyzed the carbon footprint (CF) of butter and dairy blend products, with the focus on fat content and size and type of packaging (including product waste at the consumer level). The products analyzed were butter with $80 \%$ fat in 250 -g wrap, 250 -g tub, and 10 -g mini tub, and blends with $80 \%$ and $60 \%$ fat in $250-\mathrm{g}$ tubs. Life cycle assessment was used to account for all greenhouse gas emissions from cow to consumer. A critical aspect when calculating the $\mathrm{CF}$ is how emissions are allocated between different products. Here, allocation of raw milk between products was based on a weighted fat and protein content (1:1.7), based on the price paid for raw milk to dairy farmers. The $\mathrm{CF}$ (expressed as carbon dioxide equivalents, $\mathrm{CO}_{2} \mathrm{e}$ ) for $1 \mathrm{~kg}$ of butter or blend (assuming no product waste at consumer) ranged from $5.2 \mathrm{~kg}$ (blend with $60 \%$ fat content) to $9.3 \mathrm{~kg}$ of $\mathrm{CO}_{2} \mathrm{e}$ (butter in 250-g tub). When including product waste at the consumer level, the $\mathrm{CF}$ ranged from 5.5 $\mathrm{kg}$ of $\mathrm{CO}_{2} \mathrm{e}$ (blend with $60 \%$ fat content) to $14.7 \mathrm{~kg}$ of $\mathrm{CO}_{2} \mathrm{e}$ (butter in mini tub). Fat content and the proportion of vegetable oil in products had the greatest effect on $\mathrm{CF}$ of the products, with lower fat content and a higher proportion of vegetable oil resulting in lower CF. Hence, if the same functionality as butter could be retained while shifting to lower fat and higher proportions of vegetable oil, the $\mathrm{CF}$ of the product would be decreased. Size and type of packaging were less important, but it is crucial to have the correct size and type of packaging to avoid product losses at the consumer. The greatest share of greenhouse gas emissions associated with butter production occurred at the farm level; thus, minimizing product losses in the whole

Received May 18, 2011.

Accepted August 16, 2011.

${ }^{1}$ Corresponding author: anna.flysjo@arlafoods.com value chain - from cow to consumer-is essential for efficient production.

Key words: butter, dairy production, life cycle assessment, carbon footprint

\section{INTRODUCTION}

Climate change is one of the greatest concerns facing our society (Steffen et al., 2007). The food sector represents up to about one-third of global anthropogenic greenhouse gas (GHG) emissions, if also including emissions from deforestation (Barker et al., 2007), and the Food and Agricultural Organization of the United Nations has estimated that the livestock sector is responsible for $18 \%$ of GHG emissions (Steinfeld et al., 2006). The dairy sector represents $4.0 \%$ of anthropogenic GHG emissions, including those relating to meat production from dairy-related culled and fattened animals (Gerber et al., 2010). Emissions associated solely with milk production, processing, and transportation of milk and dairy products comprise an estimated $2.7 \%$ of global anthropogenic GHG emissions (Gerber et al., 2010).

With a growing population and limited land resources for cultivation, it is evident that the food sector, and not least the dairy sector, faces a major challenge. Furthermore, with a predicted increase in demand for animal products (FAO, 2006), efficient production is crucial. The most efficient way to reduce emissions is to consider the whole value chain of a product; that is, to apply life cycle thinking. In recent years, efforts to quantify the contribution of food products to climate change have increased dramatically, resulting in several standards and guidelines on how to calculate the carbon footprint $(\mathbf{C F})$. Studies analyzing the CF (and other environmental impacts); for example, on milk and dairy products, have already been carried out in different countries (Berlin, 2002; de Vries and de Boer, 2010; Nilsson et al., 2010). Many companies, such as Arla Foods (Viby, Denmark), Fonterra (Auckland, New Zealand), Unilever (Rotterdam, the Netherlands), and Nestlé (Vevey, Switzerland), are all engaged in efforts to map the $\mathrm{CF}$ of their products. Retailers are also placing high emphasis on CF; for example, Walmart (Benton- 
ville, AR) has initiated the Sustainability Consortium, where the food industry meets to develop guidelines on how to assess the environmental impact of products, and Tesco (UK) and Casino (France) have begun to label dairy products with $\mathrm{CF}$ values. In addition to calculating a product's $\mathrm{CF}$, and thereby knowing which products have a lower contribution to climate change, life cycle assessment (LCA) is primary used to analyze "hot spots" in the value chain and thus identify where to reduce emissions most efficiently.

The present study analyzed the CF of butter produced at a dairy in Holstebro, Denmark, with the aim of identifying crucial aspects to consider in $\mathrm{CF}$ studies on butter. Nilsson et al. (2010) compared the environmental impact of butter and margarines and showed that the latter (i.e., based on vegetable raw material) gave rise to lower GHG emissions than butter, and that fat content in the product had a significant effect on the outcome. Because the greatest share of emissions occurs before the farm gate, it is important to have good data on raw milk at the farm level. The present study used more recent and detailed data to account for the full life cycle of butter and blends, whereas Nilsson et al. (2010) used published data for butter and did not include the consumer stage. Additionally, the present study analyzed different sizes and types of packaging, comparing the $\mathrm{CF}$ of different butter and blends, considering fat content and size and type of packaging, including product waste at the consumer level. The overall aim was to identify the most obvious areas for potential improvement, thus maximizing the reduction in emissions.

\section{MATERIALS AND METHODS}

Life cycle assessment is a method to assess the potential environmental impact of products or services in a life cycle perspective; that is, from cradle to grave. Such studies are typically made in accordance with the international standards ISO 14040 and 14044 (ISO, 2006a,b). Life cycle assessment is also used when calculating the CF for products, but in that case, the focus is on a single impact category; namely, the contribution to global warming. More specific recommendations on how to calculate the $\mathrm{CF}$ for dairy products are provided in IDF (2010), which was used as the basis for the present study. Analyzing the $\mathrm{CF}$ of a product includes all emissions associated with the product's life cycle expressed as carbon dioxide equivalents $\left(\mathbf{C O}_{2} \mathbf{e}\right)$. For dairy products, the most important greenhouse gases are $\mathrm{CO}_{2}, \mathrm{CH}_{4}$, and $\mathrm{N}_{2} \mathrm{O}$. The characterization factors (in a 100-yr perspective) are as follows: $1 \mathrm{~kg}$ of $\mathrm{CO}_{2}$ $=1 \mathrm{~kg}$ of $\mathrm{CO}_{2} \mathrm{e} ; 1 \mathrm{~kg}$ of $\mathrm{CH}_{4}=25 \mathrm{~kg}$ of $\mathrm{CO}_{2} \mathrm{e}$; and $1 \mathrm{~kg}$ of $\mathrm{N}_{2} \mathrm{O}=298 \mathrm{~kg}$ of $\mathrm{CO}_{2} \mathrm{e}$ (Forster et al., 2007).
Calculations in the present study were performed using the LCA software tool SimaPro7 (PRé Consultants bv., Amersfoort, the Netherlands; www.pre.nl).

\section{System Description}

Figure 1 shows the flowchart of the system investigated, which includes all activities from cow to consumer, including all farm inputs as well as waste management of consumer packaging. The products analyzed in the present study were produced by Arla Foods at the Holstebro dairy in Denmark, and the production flows are illustrated in Figure 2. Milk produced on Danish dairy farms is collected and transported to the nearest dairy. To maximize efficiency of production, all Arla Foods dairies are specialized and more than $80 \%$ of the Arla Foods butter and blends in Denmark are produced at the Holstebro site. Thus, a large amount of cream from other sites is transported to Holstebro and used for butter production. Besides butter, the Holstebro Dairy produces some secondary products (skim milk, cream, and buttermilk), which are primarily used in soft cheese production.

\section{Functional Unit}

The functional unit (FU) is a quantified performance parameter of a product system under analysis to which all inputs and outputs (or interventions) in that product system are referred. In this study, $2 \mathrm{FU}$ were defined: (1) $1 \mathrm{~kg}$ of packaged butter or blend provided at the customer level in Denmark, and (2) $1 \mathrm{~kg}$ of packaged butter or blend consumed in Denmark.

The only difference between the $2 \mathrm{FU}$ is that product waste at the consumer stage was included for the second FU. As relatively large uncertainties exist regarding food waste at the consumer level, we chose to show results both excluding and including consumer product waste. The actual products compared were (1) four 250g packs of wrapped butter ( $80 \%$ fat, $0.60 \%$ protein) at a household in Denmark; (2) four 250-g tubs of butter ( $80 \%$ fat and $0.60 \%$ protein) at a household in Denmark; (3) one hundred 10-g mini tubs of butter $(80 \%$ fat and $0.60 \%$ protein) at a restaurant in Denmark; (4) four $250-\mathrm{g}$ tubs of blend [ $80 \%$ fat $(68.5 \%$ butter + $31.5 \%$ vegetable oil), $0.50 \%$ protein] at a household in Denmark; and (5) four 250-g tubs of blend $[60 \%$ fat ( $63 \%$ butter $+37 \%$ vegetable oil), $0.40 \%$ protein] at a household in Denmark.

\section{Allocation}

Some activities give rise to more than one product; for example, a dairy cow produces milk but also ap- 


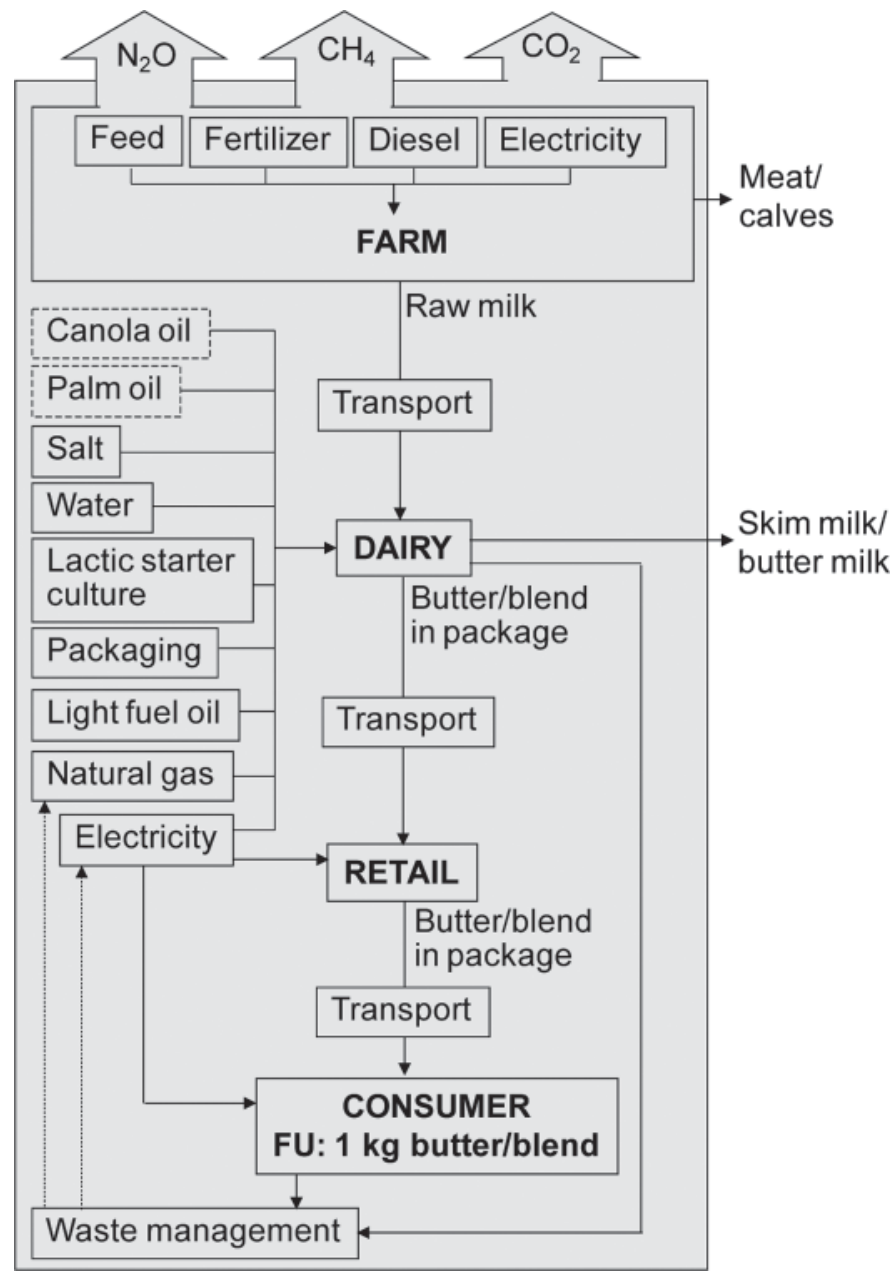

Figure 1. Flowchart of the life cycle for the butter and the blend products illustrating the system boundaries (inputs in dotted boxes apply only to blend). $\mathrm{FU}=$ functional unit.

proximately one calf per year and meat when it is slaughtered. Thus, when analyzing milk only, it is necessary to split the emissions associated with the cow between the different products. Similarly, at dairy production plants, cream and skim milk are produced from raw milk, and butter and buttermilk are products from the cream.

In this study, the allocation mainly followed the recommendations in IDF (2010). Thus, the CF for raw milk from the farm was calculated by applying a physical causality allocation factor between milk and calves or meat (IDF, 2010), resulting in $76 \%$ of emissions being allocated to milk (Kristensen et al., 2011). At dairy production plants, the allocation of raw milk between products is based on a weighted fat and protein content (1:1.7), based on the price of raw milk to dairy farmers. This is a slightly different approach than presented in IDF (2010), which recommends allocation based on milk solids (Feitz et al., 2007). The use of energy and

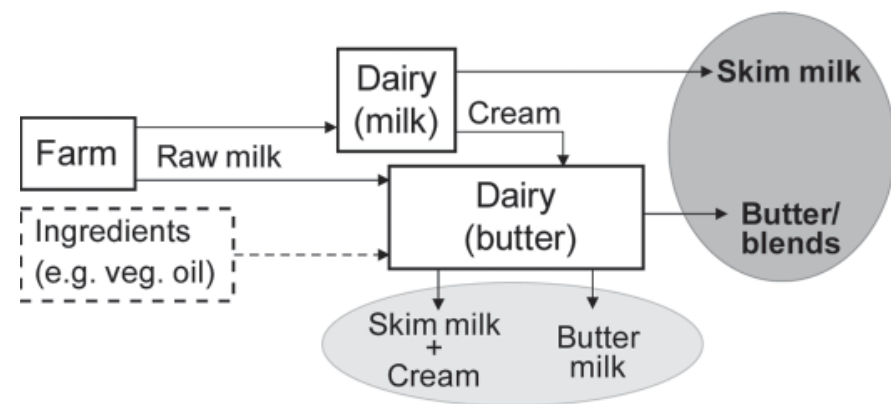

Figure 2. Flowchart of butter and blend production. Darker shading indicates main (consumer) products and lighter shading indicates secondary products.

other inputs at the Holstebro dairy site were analyzed to estimate the share for different operations; that is, a subdivision of total use between different activities (e.g., energy used for storage was only allocated to products that are stored). When it was not possible to divide a process, allocation was based on the same value as raw milk (i.e., energy for the churning process was allocated based on the weighted fat and protein content in butter and buttermilk). For other inputs (e.g., vegetable oils), economic allocation was applied according to IDF (2010).

\section{Data Used and System Boundaries}

This study focused on the production of butter. To obtain as detailed data as possible, specific data on butter production were obtained directly from Arla Foods dairies, whereas data for the rest of the butter life cycle were taken from the literature. Moreover, the study assumed that both production and consumption of the butter took place in Denmark. Emissions associated with capital goods were included for transport (e.g., manufacturing of vehicles) and energy supply (e.g., construction of power plants), but not for dairy production plants or farm buildings. The electricity used was assumed to correspond to the average Danish electricity grid mix (including grid losses). Emissions relating to production of inputs for the system, except raw milk, were taken primarily from a well-established database (Ecoinvent, 2010). Concerning data quality, the study applied the most up-to-date, detailed, and comprehensive data sets available. The level of consistency between the data sets was considered high, and the same methodological choices (e.g., regarding allocation) were made in each of the scenarios being compared. The various activities in the production chain are described below.

Farm. The CF for raw milk (when using a physical causality allocation that resulted in $76 \%$ of total 
Table 1. Composition (\%) of the different products analyzed

\begin{tabular}{lcccccc}
\hline Product & Butter & $\begin{array}{c}\text { Canola } \\
\text { oil }\end{array}$ & $\begin{array}{c}\text { Palm } \\
\text { oil }\end{array}$ & $\begin{array}{c}\text { Lactic starter } \\
\text { culture }\end{array}$ & Salt & Water \\
\hline Butter 80\% fat & 96.0 & - & - & 2.8 & 1.2 & - \\
Blend 80\% fat & 68.5 & 25.2 & - & 2.0 & 0.9 & 3.4 \\
Blend 60\% fat & 47.2 & 21.8 & 0.4 & 2.0 & 0.9 & 27.7 \\
\hline
\end{tabular}

emissions being allocated to milk) was taken as 0.91 $\mathrm{kg}$ of $\mathrm{CO}_{2} \mathrm{e} / \mathrm{kg}$ of ECM at the farm gate (Kristensen et al., 2011). This value was based on data from 35 conventional dairy farms in Denmark and was considered representative for average Danish milk production.

Milk Collection. The average distance for milk collection from farms in Denmark was estimated to be 50 km (C. Nielsen, Arla Foods, personal communication). Associated emissions (per t. $\mathrm{km}$ ) for transportation by truck (16-32 t) were taken from Ecoinvent (2010).

Dairy Production. Total production of butter and blend products at Holstebro Dairy in 2009 was $108,000 \mathrm{t}$, with additional by-products of $74,000 \mathrm{t}$ of cream (with a low fat content of about 17\%), 97,000 $\mathrm{t}$ of buttermilk, and 11,000 t of skim milk. All data relating to dairy production were collected at Arla Foods production facilities. Data for cream, which is a major input to butter production, were collected at 3 milk handling facilities (representing about $20 \%$ of the cream delivered to Holstebro), and the cream was assumed to be transported approximately $150 \mathrm{~km}$ on average. The total amount of cream delivered to Holstebro dairy was 192,000 t (38.5\% fat, $2.16 \%$ protein). Additionally, $52,000 \mathrm{t}$ of raw milk $(4.11 \%$ fat, $3.35 \%$ protein) was delivered directly from farms. Some product losses are unavoidable due to cleaning of machinery. At Holstebro, such product losses were $<1 \%$ based on fat and protein content and accounted for in the study. The total amount of energy used at Holstebro Dairy was 39,600 GJ of electricity, $1,230,000 \mathrm{~m}^{3}$ of natural gas, and 12,000 L of light fuel oil. Data on production and combustion of energy carriers were taken from Ecoinvent (2010). The CF data for the vegetable oil used in the blends were taken from Schmidt (2007). No $\mathrm{CF}$ data on lactic starter culture were found, but the
$\mathrm{CF}$ was estimated at $10 \mathrm{~kg}$ of $\mathrm{CO}_{2} \mathrm{e}$ per $\mathrm{kg}$ (M. Thrane, Danisco, Aarhus, Denmark, personal communication). The CF data for salt were taken from the ETH-ESU database (Frischknecht et al., 1996) and data for water from the Ecoinvent database (Ecoinvent, 2010). The composition of the products studied is presented in Table 1.

Packaging. Data on types and amounts of specific packaging used were obtained from Arla Foods (Table 2 ). Data on production of different packaging materials were taken from Ecoinvent (2010), representing average European conditions.

Distribution and Retail. Transport from dairy production plant (Holstebro) to retail store or restaurant (Copenhagen, Denmark) covered $350 \mathrm{~km}$, and emissions (per t. $\mathrm{km}$ ) for transportation by truck (16-32 t) were taken from Ecoinvent (2010). At the store, the butter product was assumed to be stored for approximately 10 d. Energy use for chilled storage (K. Nilsson, the Swedish Institute for Food and Biotechnology, Gothenburg, Sweden, personal communication) and emissions of cooling agents (Thrane, 2004) were accounted for. Total energy use for $1 \mathrm{~kg}$ of butter product at the store was estimated to be 0.15 MJ (allocated based on volume). Energy use for lighting was not included. The same assumptions and data were used for the mini tub, as the storage time was similar.

Consumer. Emissions associated with the transportation of products from store to consumer (customer level) are difficult to estimate, because a large number of assumptions are required (shopping frequency, distance traveled, amount of trips made by car, allocation between different groceries). No data were found for consumer travel in Denmark, so data for shopping trips in Sweden were used instead. The average distance

Table 2. Composition and total weight (g per pack) of the different consumer packaging ${ }^{1}$

\begin{tabular}{llllc}
\hline Product/package & Wrap & Tub & Cut-lid & Lid/top \\
\hline Butter 80\% fat, 250-g wrap & PE/paper/Al & - & - & - \\
Butter 80\% fat, 250-g tub & - & $\mathrm{PP} /$ paper & $\mathrm{PE} /$ paper/Al & $\mathrm{PP} /$ paper \\
Butter 80\% fat, 10-g mini tub & - & $\mathrm{PS}$ & $\mathrm{PE} / \mathrm{PET}$ & 2.9 \\
Blend 80\% fat, 250-g tub & - & $\mathrm{PS} / \mathrm{PET} /$ paper & $\mathrm{PE} /$ paper/Al & $\mathrm{PP}$ \\
Blend 60\% fat, 250-g tub & - & $\mathrm{PS} / \mathrm{PET} /$ paper & $\mathrm{PE} /$ paper/Al & $\mathrm{PP}$ \\
\hline
\end{tabular}

${ }^{1} \mathrm{PE}=$ polyethylene; $\mathrm{PP}=$ polypropylene $\mathrm{PS}=$ polystyrene; $\mathrm{PET}=$ polyethylene terephthalate $\mathrm{Al}=$ aluminum. 
traveled by car from store to consumer was estimated to be (at least) $13 \mathrm{~km}$ per person and week (Sonesson et al., 2005). Based on national statistics, the total amount of groceries purchased was estimated (Swedish Board of Agriculture, www.sjv.se), resulting in 1.7 MJ of gasoline $/ \mathrm{kg}$ of groceries (allocated on mass basis). At the consumer's home, the butter product was assumed to be stored for $20 \mathrm{~d}$ in the refrigerator. Energy use for refrigerator was included (K. Nilsson, Swedish Institute for Food and Biotechnology, Gothenburg, Sweden, personal communication), but not energy for food preparation or dishwashing. Total energy use for storage in refrigerator was calculated to $0.66 \mathrm{MJ} / \mathrm{kg}$ of product (allocated based on volume). No specific data on energy use in restaurants were found and because the storage time was similar, the same data were used for all products investigated, except for home transport, which was excluded for butter in the mini tub.

One main difference between the products is likely the amount of product waste at the consumer stage. No specific figures were found on product waste at consumer for different butter products, but a study conducted in the United Kingdom showed that 9\% of purchased dairy products are wasted at the consumer level, with $8 \%$ being avoidable waste (WRAP, 2009). To differentiate between different types of products (i.e., packages), experts were consulted and agreed that the $250-\mathrm{g}$ plastic tub resulted in the lowest waste, wrap in somewhat higher waste, and mini tub having the greatest amount of waste. A rough estimate of product waste for each package was 5,10 , and $25 \%$, respectively. In addition, a sample of mini tubs was collected to establish the share of butter wasted (as this was the type of package assumed to have the largest waste). The mini tubs were collected after being thrown away at lunch in a canteen; in total, 73 packages were collected and weighed, showing an average waste of $37 \%$. Thus, the numbers used for quantifying the product waste at the consumer level were $5 \%$ for 250 -g tub, $10 \%$ for 250 -g wrap, and $37 \%$ for mini tub.

Waste and Wastewater Management. The waste contribution analyzed included all waste and wastewater at the dairy plant, as well as all packaging used for the product (i.e., both primary and secondary packaging). The waste was assumed to go to municipal waste management for incineration with heat recovery, which is the most common method in Denmark. Energy recovery at the waste incineration plant was assumed to be 3.5 MJ of electricity and 7.0 MJ of thermal energy per $1 \mathrm{~kg}$ of plastic, and $1.3 \mathrm{MJ}$ of electricity and $2.8 \mathrm{MJ}$ of thermal energy per $1 \mathrm{~kg}$ of paper (Ecoinvent, 2010). The electricity and heat recovered were assumed to replace the same amount of electricity (average Danish mix) and heat (natural gas). Some waste at the dairy plant also goes to recycling and then a cut-off is applied (i.e., the cost and benefits of the recycling is allocated to the life cycle in which the material is used next). The contribution from wastewater management was taken as the energy associated with treating wastewater from the dairy plant at a municipal wastewater treatment plant.

\section{Sensitivity Analysis and Potential for Improvement}

A sensitivity analysis was conducted to investigate how the final $\mathrm{CF}$ result changed as a response to changes in various parameters and to analyze potential improvements regarding GHG emissions. The $\mathrm{CF}$ of milk, vegetable oils, lactic starter culture, and packaging, as well as energy use at the dairy plants and transportation (except transport from retail to consumer) were reduced by $25 \%$ to analyze how these theoretical improvements would reduce the $\mathrm{CF}$ of butter. Moreover, a sensitivity analysis was conducted on different allocation methods (fat and protein with same weighting and total milk solids) for the butter and its co-products.

\section{RESULTS}

\section{Carbon Footprint}

The CF (excluding and including product waste at consumer, respectively) were found to be 9.0 and 10.0 $\mathrm{kg}$ of $\mathrm{CO}_{2} \mathrm{e} / \mathrm{kg}$ of butter in $250-\mathrm{g}$ wrap; 9.3 and $9.8 \mathrm{~kg}$ of $\mathrm{CO}_{2} \mathrm{e} / \mathrm{kg}$ of butter in $250 \mathrm{-g}$ tub; 9.2 and $14.7 \mathrm{~kg}$ of $\mathrm{CO}_{2} \mathrm{e} / \mathrm{kg}$ of butter in 10-g mini tub; 6.8 and $7.1 \mathrm{~kg}$ of $\mathrm{CO}_{2} \mathrm{e} / \mathrm{kg}$ of blend product in $250-\mathrm{g}$ tub; and 5.2 and $5.5 \mathrm{~kg} \mathrm{CO} 2 \mathrm{e} / \mathrm{kg}$ of lower fat blend product in $250 \mathrm{-g}$ tub (Figure 3). Raw milk (i.e., all emissions associated with activities before the farm gate for both milk and cream) represented the largest share of the CF of butter (80$85 \%$ ) and blends (70-75\%). Vegetable oils represented 8 to $10 \%$ of the total CF for the blend products. Other inputs (e.g., other ingredients, chemicals, water) corresponded to about 4 to $5 \%$ of total CF for all products, with production of the lactic starter culture dominating these emissions. Emissions associated with energy use at dairies were similar for all products, representing approximately $4 \%$ of total $\mathrm{CF}$. The packaging with the lowest $\mathrm{CF}$ was the wrapping ( $1 \%$ of $\mathrm{CF}$ ), whereas that with the largest $\mathrm{CF}$ per $\mathrm{kg}$ of product was the mini tub (6\% of $\mathrm{CF}$ ). All transport (except that from retail to consumer) contributed approximately $2 \%$ of total CF. Emissions from the latter part of the life cycle (retail and consumer) accounted for about 1 to $5 \%$ of total $\mathrm{CF}$ (the blend products had a relatively higher share due to their lower total $\mathrm{CF}$ ), with transport from retail 


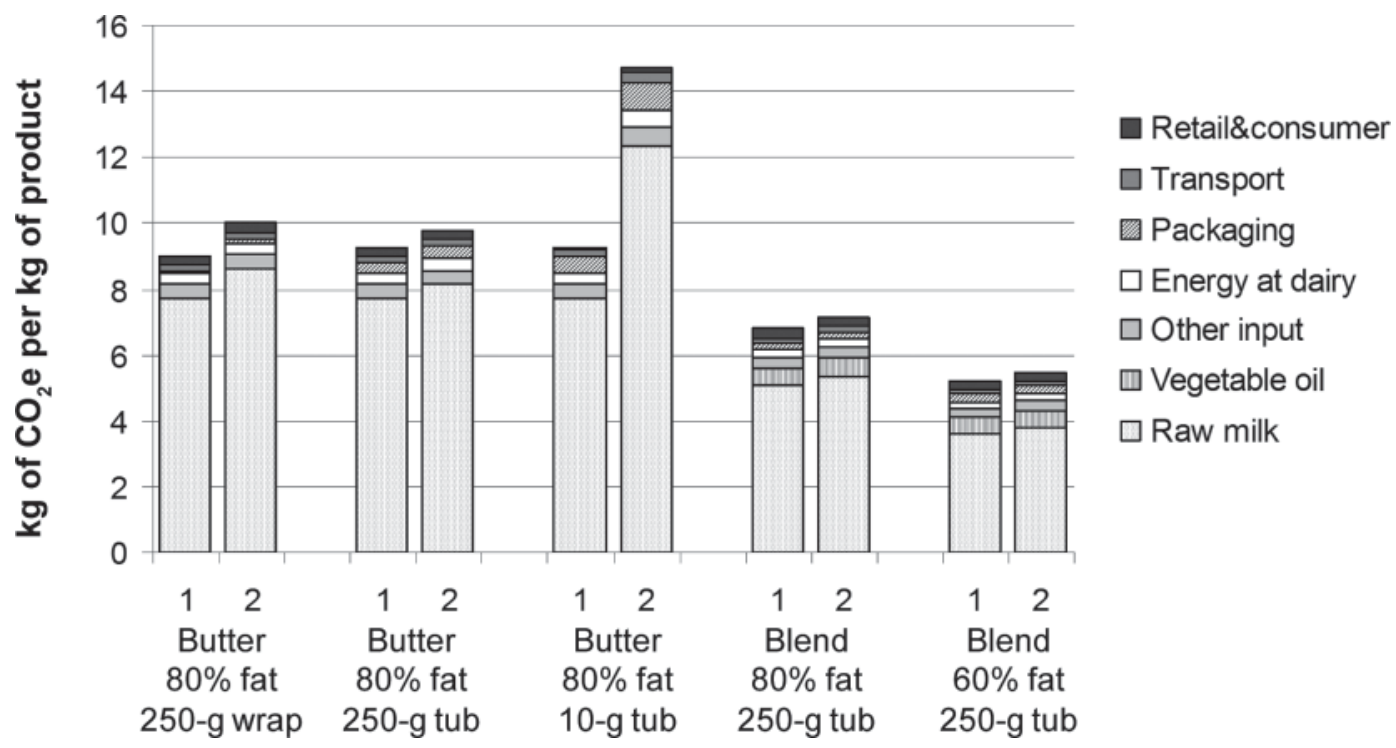

Figure 3. Carbon footprint (in $\mathrm{kg}$ of $\mathrm{CO}_{2}$ equivalents, $\mathrm{CO}_{2} \mathrm{e}$ ) of $1 \mathrm{~kg}$ of butter or blend provided at consumer (1) and consumed (2) divided across different activities in the life cycle.

to consumer being responsible for about $85 \%$ of this (except for the mini tub, as no consumer transport was assumed).

\section{Potential Improvements}

The results of the sensitivity analysis (Table 3) clearly showed that the greatest potential for improvement was at the farm level, because a total reduction of about $20 \%$ could be achieved for the different products investigated in this study if emissions related to production of raw milk were reduced by $25 \%$. Reducing the emissions associated with other ingredients (lactic starter culture or vegetable oils in the case of blends) by $25 \%$ would result in a reduction corresponding to 1 to $3 \%$ in total $\mathrm{CF}$ of the final product. A $25 \%$ reduction in the emissions associated with energy use at dairy sites, packaging, and transportation would result in an approximately 2 to $3 \%$ lower $\mathrm{CF}$ in total. It should be acknowledged, however, that emissions at the farm level comprise methane and nitrous oxide (70-90\%; Thomassen et al., 2008; Flysjö et al., 2011b) from natural bio- logical processes and therefore are much more difficult to reduce than emissions from, for example, combustion of fossil fuels. Hence, a 25\% reduction might not be realistic for all dairy farms.

\section{DISCUSSION}

The CF results for all butter types were similar (not accounting for product waste), whereas the blends had significantly lower CF; the blend with $60 \%$ fat had the lowest CF, followed by the blend with $80 \%$ fat, whereas butter had the highest CF. Because the same raw milk was assumed to be used for all products in the present study, the precise CF of raw milk was not crucial for the outcome (i.e., it did not differ across the different products). However, if raw milk had a higher $\mathrm{CF}$, the milk component would obviously represent a greater proportion of the CF for each product, and vice versa. When comparing the results of the present study with $\mathrm{CF}$ values for dairy products in other studies, it is important to consider how the $\mathrm{CF}$ of the raw milk is calculated, as it can significantly affect the results (Flysjö

Table 3. Potential for improving the carbon footprint (CF) of butter and blend products expressed as percentage change in $\mathrm{CF}$

\begin{tabular}{|c|c|c|c|c|c|}
\hline Item & $\begin{array}{c}\text { Butter } 80 \% \text { fat, } \\
250 \text {-g wrap }\end{array}$ & $\begin{array}{c}\text { Butter } 80 \% \text { fat, } \\
250 \text {-g tub }\end{array}$ & $\begin{array}{c}\text { Butter } 80 \% \text { fat, } \\
10 \text {-g mini tub }\end{array}$ & $\begin{array}{l}\text { Blend } 80 \% \text { fat, } \\
250-\mathrm{g} \text { tub }\end{array}$ & $\begin{array}{c}\text { Blend } 60 \% \text { fat } \\
250-\mathrm{g} \text { tub }\end{array}$ \\
\hline $\begin{array}{l}-25 \% \text { in } \mathrm{CF} \text { of raw milk } \\
-25 \% \text { in } \mathrm{CF} \text { of vegetable oil } \\
-25 \% \text { in } \mathrm{CF} \text { of lactic starter culture } \\
-25 \% \text { in energy use } \\
-25 \% \text { in } \mathrm{CF} \text { of packaging } \\
-25 \% \text { in transportation }\end{array}$ & $\begin{array}{l}-21.50 \\
-0.78 \\
-1.39 \\
-0.23 \\
-0.49\end{array}$ & $\begin{array}{l}-20.85 \\
-0.75 \\
-1.35 \\
-0.97 \\
-0.48\end{array}$ & $\begin{array}{r}-20.94 \\
-0.76 \\
-1.36 \\
-1.41 \\
-0.48\end{array}$ & $\begin{array}{r}-18.63 \\
-2.06 \\
-0.74 \\
-1.33 \\
-0.84 \\
-0.50\end{array}$ & $\begin{array}{r}-17.40 \\
-2.38 \\
-0.96 \\
-1.38 \\
-1.10 \\
-0.55\end{array}$ \\
\hline
\end{tabular}


et al., 2011a,b; Henriksson et al., 2011). Another aspect to consider, when comparing with other studies and to some extent for the present study, is how the raw milk is allocated between butter and its co-products. Allocation based on the economic value of the products is commonly used in LCA, but this is difficult to apply for dairy products, because many intermediate products (e.g., cream used in butter production) do not have a real price (as they are sold between sites within one dairy company). Another basis for allocation could be milk solids content or equal weight of fat and protein. If allocation were to be based on equal weight of fat and protein, the $\mathrm{CF}$ results in the present study would increase by $21 \%$ ( $60 \%$ fat blend in tub) to $27 \%$ ( $80 \%$ fat butter in wrap). In contrast, if the method suggested in IDF (2010) were applied (i.e., allocation of milk based on milk solids), the results would decrease by $20 \%$ ( $60 \%$ fat blend in tub) to $24 \%$ ( $80 \%$ fat butter in wrap). Valuing all components (milk solids) equally does not reflect the reason for production; for example, lactose is not as valuable as fat and protein and if milk contained only lactose, it would be questionable whether we have milk production. Furthermore, protein has a higher value than fat. Therefore, using a weighted allocation factor for dairy products, based on the value of fat and protein, makes sense as it reflects the drivers behind production. Comparison of the results in the present study with those reported by Nilsson et al. (2010; butter produced in Denmark and distributed to the United Kingdom) and Sheane et al. (2011; butter produced and consumed in Scotland) show that the final CF numbers for butter are similar (9.0, 9.6, and 8.9, respectively). However, the $\mathrm{CF}$ numbers for raw milk as well as the allocation factor for butter were different in the studies. If the studies were based on the same underlying assumptions (e.g., allocation method), the CF of butter in the present study would likely been the lowest, because the CF number used for raw milk was the lowest. Hence, it is important not only to compare final $\mathrm{CF}$ results, but also to evaluate the underlying methodology.

\section{Functionality of Product}

The most significant reduction in GHG emissions for butter and blend products could be achieved by increasing the proportion of vegetable oil and reducing the fat content in the products. However, replacing the dairy part in butter would also likely affect the quality and application; that is, the function of the product. Butter is considered a higher value product; for example, it has a better taste. It is important to consider also whether the same amount of product is used or whether more of the lower fat blend would be needed to provide the same function as butter. If twice the amount of lowfat blend were used, it would not be environmentally preferable compared with butter. Comparing the same amount of fat (i.e., shifting the functional unit to 1 $\mathrm{kg}$ of fat instead of $1 \mathrm{~kg}$ of product) would obviously increase the CF for $60 \%$ fat blend, resulting in a similar $\mathrm{CF}$ as for $80 \%$ fat blend, but the butter products would still have a higher CF. Products with higher fat content can be used for cooking (e.g., frying) and as a spread, whereas blends with lower fat content can only be used for the latter (although all products in this study can be used for cooking). However, if the same functionality as butter can be retained while shifting to lower fat and a higher proportion of vegetable oil, the CF of the product would be reduced. Similar conclusions were reached by Nilsson et al. (2010) when comparing butter and spreads.

\section{Post-Farm Activities}

Even though the raw materials in the products (raw milk and vegetable oil) comprise the predominant share of total $\mathrm{CF}$, the remaining activities contribute about 15 to $20 \%$. Although transport, retail factors, and consumer factors were similar for all products, some differences were found in other inputs (primarily the lactic starter culture) and energy in dairy plants, where products containing more milk also give rise to more emissions. For the mini tub, we assumed no consumer transport, which resulted in butter in the mini tub having a slightly lower CF than butter in the 250 -g tub. The consumer transport incorporates many underlying assumptions and for butter in the 250-g tub, it represents $2 \%$ of the CF. As no LCA data on lactic starter culture were found, a conservative estimate was used, but this did not affect the conclusions of the present study. The largest difference in $\mathrm{CF}$ between the products studied, besides raw materials, was for packaging. Both type and amount of packaging material influenced the $\mathrm{CF}$, with use of a bio-based material (assuming the packaging goes to waste incineration after use and the energy generated replaces fossil energy) and minimizing the amount of packaging per product resulting in lower CF. However, the most important factor was that packaging size should be adapted to consumer needs, because any waste of product (butter or blend) had a much higher effect on the CF than did extra packaging. Thus, incorporating product waste at the consumer level for the butter resulted in the $250-\mathrm{g}$ tub having the lowest $\mathrm{CF}$, followed by the wrap and the mini tub, with the largest CF. Consequently, one of the main improvements a dairy company can make in regard to reducing the $\mathrm{CF}$ from products is to design packaging that minimizes waste at the consumer level. If the product waste from 
the mini tubs could be halved (i.e., from 37 to $19 \%$ ), the $\mathrm{CF}$ for the butter would be reduced by more than $20 \%$ (or $3 \mathrm{~kg}$ of $\mathrm{CO}_{2} \mathrm{e}$ per $\mathrm{kg}$ of butter). One way to address food waste is to adjust packaging size to better reflect consumer requirements. Other parameters that may influence food waste are shelf life and packaging shape. Regarding packaging shape, it is important that packages are convenient to use and easy to empty, but it is also important not to shift the burden to more environmentally harmful packaging.

\section{CONCLUSIONS}

Because milk as a raw material has a relatively high $\mathrm{CF}$, it is crucial to use it as efficiently as possible and to minimize losses throughout the product chain from cow to consumer. Relatively small improvements at the farm level can yield high benefits for the final product; for example, a $5 \%$ reduction in emissions at the farm level is more beneficial than a $50 \%$ reduction in energy use at the dairy plant. Share of vegetable oil and fat content in products have the largest effect on the $\mathrm{CF}$, with the lowest fat content and the lowest fraction of butter (dairy part) resulting in the lowest $\mathrm{CF}$. The quality and application of butter and blends differ, and it is therefore difficult to make a fair comparison. However, if the same functionality as butter could be retained in a blend while shifting to lower fat and a higher proportion of vegetable oil, the $\mathrm{CF}$ of the product would be reduced.

\section{ACKNOWLEDGMENTS}

The study was performed with funding from the Danish Agency for Science, Technology and Innovation (Copenhagen, Denmark).

\section{REFERENCES}

Barker, T., I. Bashmakov, L. Bernstein, J. E. Bogner, P. R. Bosch, R. Dave, O. R. Davidson, B. S. Fisher, S. Gupta, K. Halsnæs, G. J. Heij, S. Kahn Ribeiro, S. Kobayashi, M. D. Levine, D. L. Martino, O. Masera, B. Metz, L. A. Meyer, G.-J. Nabuurs, A. Najam, N. Nakicenovic, H.-H. Rogner, J. Roy, J. Sathaye, R. Schock, P. Shukla, R. E. H. Sims, P. Smith, D. A. Tirpak, D. Urge-Vorsatz, and D. Zhou. 2007. Technical Summary. Pages 25-94 in Climate Change 2007: Mitigation. Contribution of Working Group III to the Fourth Assessment Report of the Intergovernmental Panel on Climate Change. B. Metz, O. R. Davidson, P. R. Bosch, R. Dave, and L. A. Meyer, ed. Cambridge University Press, Cambridge, UK, and New York, NY.

Berlin, J. 2002. Environmental life cycle assessment (LCA) of Swedish semi-hard cheese. Int. Dairy J. 12:939-953.

de Vries, M., and I. J. M. de Boer. 2010. Comparing environmental impacts for livestock products: A review of life cycle assessments. Livest. Sci. 128:1-11.

Ecoinvent. 2010. Ecoinvent data v2.2. Final Reports No. 1-25. CDROM. Swiss Centre for Life Cycle Inventories, Dübendorf, Switzerland.
FAO. 2006. World agriculture: Towards 2030/2050. Interim report. Prospects for food, nutrition, agriculture and major commodity groups. Global Perspective Studies Unit, Food and Agriculture Organization of the United Nations, Rome, Italy.

Feitz, A. J., S. Lundie, G. Dennien, M. Morain, and M. Jones. 2007. Generation of an industry-specific physico-chemical allocation matrix, application in the dairy industry and implications for system analysis. Int. J. Life Cycle Assess. 12:109-117.

Flysjö, A., C. Cederberg, M. Henriksson, and S. Ledgard. 2011a. How does co-product handling affect the carbon footprint of milk? Case study of milk production in New Zealand and Sweden. Int. J. Life Cycle Assess. 16:420-430.

Flysjö, A., M. Henriksson, C. Cederberg, S. Ledgard, and J.-E. Englund. 2011b. The impact on various parameters on the carbon footprint of milk production in New Zealand and Sweden. Agric. Syst. 104:459-469.

Forster, P., V. Ramaswamy, P. Artaxo, T. Berntsen, R. Betts, D. W. Fahey, J. Haywood, J. Lean, D. C. Lowe, G. Myhre, J. Nganga, R. Prinn, G. Raga, M. Schulz, and R. Van Dorland. 2007. Changes in atmospheric constituents and in radiative forcing. Pages 129-234 in Climate Change 2007: The Physical Science Basis. Contribution of Working Group I to the Fourth Assessment Report of the Intergovernmental Panel on Climate Change. S. Solomon, D. Qin, M. Manning, Z. Chen, M. Marquis, K. B. Averyt, M. Tignor, and H. L. Miller, ed. Cambridge University Press, Cambridge, UK, and New York, NY.

Frischknecht, R., U. Bollens, S. Bosshart, M. Ciot, L. Ciseri, G. Doka, R. Dones, U. Gantner, R. Hischier, and A. Martin. 1996. Ökoinventare von Energiesystemen. Grundlagen für den ökologischen Vergleich von Energiesystemen und den Einbezug von Energiesystemen in Ökobilan-zen für die Schweiz. Auflage No. 3. Gruppe Energie-Stoffe-Umwelt (ESU), Eidgenössische Technische Hochschule Zürich und Sektion Ganzheitliche Systemanalysen. Paul Scherrer Institute, Bern, Switzerland.

Gerber, P., T. Vellinga, C. Opio, B. Henderson, and H. Steinfeld. 2010. Greenhouse Gas Emissions from the Dairy Sector, A Life Cycle Assessment. FAO Food and Agriculture Organisation of the United Nations, Animal Production and Health Division, Rome, Italy.

Henriksson, M., A. Flysjö, C. Cederberg, and C. Swensson. 2011. Variation in carbon footprint of milk due to management differences between Swedish dairy farms. Animal 5:1474-1484. doi:10.1017/ S1751731111000437.

IDF. 2010. A common carbon footprint for dairy, The IDF Guide to Standard Lifecycle Assessment Methodology for the Dairy Industry. International Dairy Federation, Brussels, Belgium.

ISO. 2006a. Environmental management: Life cycle assessment-Principles and framework. ISO 14040:2006 (E). International Organization for Standardization, Geneva, Switzerland.

ISO. 2006b. Environmental management: Life cycle assessment-Requirements and guidelines. ISO 14044:2006 (E). International Organization for Standardization, Geneva, Switzerland.

Kristensen, T., L. Mogensen, M. Trydeman Knudsen, and J. E. Hermansen. 2011. Effect of production system and farming strategy on greenhouse gas emissions form commercial dairy farms in a life cycle approach including effect of different allocation methods. Livest. Sci. 140:136-148. doi:10.1016/j.livsci.2011.03.002.

Nilsson, K., A. Flysjö, J. Davis, S. Sim, N. Unger, and S. Bell. 2010. Comparative life cycle assessment for margarine and butter consumed in UK, Germany and France. Int. J. Life Cycle Assess. 15:916-926.

Schmidt, J. H. 2007. Life cycle assessment of rapeseed oil and palm oil. Part 3: Life cycle inventory of rapeseed oil and palm oil. PhD Thesis. Department of Development and Planning, Aalborg University, Aalborg, Denmark.

Sheane, R., K. Lewis, P. Hall, P. Homes-Ling, A. Kerr, K. Stewart, and D. Webb. 2011. Identifying opportunities to reduce the carbon footprint associated with the Scottish dairy supply chain. Main report. Scottish Government, Edinburgh, UK.

Sonesson, U., F. Anteson, J. Davis, and P.-O. Sjödén. 2005. Home transport and wastage: Environmentally relevant household activities in the life cycle of food. Ambio 34:371-375. 
Steffen, W., P. J. Crutzen, and J. R. McNeill. 2007. The Anthropocene: Are humans now overwhelming the great forces of Nature? Ambio 36:614-621.

Steinfeld, H., P. Gerber, T. Wassenaar, V. Castel, M. Rosales, and C. de Haan. 2006. Livestock's Long Shadow: Environmental Issues and Options. Food and Agriculture Organization of the United Nations, Rome, Italy.

Thomassen, M. A., K. J. van Calker, M. C. J. Smits, G. L. Iepema, and I. J. M. de Boer. 2008. Life cycle assessment of conventional and organic milk production in the Netherlands. Agric. Syst. 96:95-107.

Thrane, M. 2004. Environmental impacts from Danish fish productsHot spots and environmental policies. PhD Diss. Department of Development and Planning, Aalborg University, Aalborg, Denmark.

WRAP. 2009. Household Food and Drink Waste in the UK. WRAP (Waste and Resources Action Programme), Banbury, UK. 